\title{
Designing and 3-D Modelling of a Sustainable Cable Stayed Bridge- A Case Study
}

\author{
Priyanka Singh ${ }^{1, *}$, Mirza Jahangir Baig ${ }^{1}$, Bhumika Pandey ${ }^{1}$, and Kartik Papreja ${ }^{1}$ \\ ${ }^{1}$ Department of Civil Engineering, Amity School of Engineering \& Technology, Amity University Uttar Pradesh, Noida, India
}

\begin{abstract}
In the world of Civil Engineering, bridges are an example of structural art expressing how much the structures have evolved till present times. The concept and design of bridges has been evolved over the past years, having numerous amounts of different geometrical models and methods to construct bridges. As the development and innovation has reached so far, the concept of bridges has made a great impact on global infrastructure by creating sustainable, effective, and aesthetical bridges around the world. development of the finest aesthetical and sustainable designs for bridges which are known as Cable Stayed BridgesThe bridge form in which the weight of the deck is supported by a number of nearly straight diagonal cables in tension running directly to one or more vertical towers. The towers transfer the cable forces to the foundations through vertical compression. The tensile forces in the cables also put the deck into horizontal compression. Cable stayed bridges are the types of bridges those are best suited for connecting wide-span crossings. Construction of cable stayed bridge is widely promoted all over the world and construction of more than 600 cable stayed bridges are recorded till date. This type of bridge is preferred over any other type due to its possible construction to the indefinite length, availability of multiple design options with the possibility of symmetrical design and excellent strength. In this paper we shall discuss numerous case studies of the cable stayed bridges, compile all the beneficial data for most of the cable stayed bridges located in India.
\end{abstract}

\section{Introduction}

The introduction to cable stayed bridge was done along with that of the suspension bridge, however due the initial collapse of the cable supported bridges those were constructed over the river Tweed (Europe) and Saale(Germany), at the beginning of 19th century, the concept was deserted. A huge number of bridges were destructed, due to the result of World War II. It became necessary to reconstruct them after the war. The steel at that given time was very less in amount and new bridges were supposed to be constructed with the least possible weight. The main aim of construction was providing economical material and most importantly cost; hence engineers adopted the concept of the cable stayed bridge. The Stromsund Bridge (Sweden) in 1955 was the first modern cable stayed bridge [1]. Cable Stayed Bridges mostly are taken in account for structures which requires large span and for aesthetical purposes [2]. These structures use high strength of steel cables as axial force resistant members, mostly seen in cable supported bridges [3]. Cable stayed bridges, as the name suggests follow the principle of cables acting as a tension resistance structural member where the load is transferred to the pylon to the piles [4]. Since the 21st century, cable-stayed bridges have gained popularity all over the world when construction is required for spans up to approximately $1 \mathrm{~km}$. The major reasons being the appealing aesthetics, less time taken for construction, efficiently using the materials for building structure, light appearance, and importantly increase in stiffness when compared to suspension bridges. Structure with these characteristics, are further characterized by a longlife period, large flexibility, light weight, and low structural damping $[5,6]$. These conveniences have promoted the following case studies of the cable stayed bridges in India. The first ever study of cable stayed bridge was observed in early 1595 by Renaissance Polymath and Fausto Veeranzio as chain stayed bridges, adapting the similar design, various adjustments has been done in reshaping cable stayed bridge models and after that various developments have been made and it took rapid pace since 1990's. With the help of Innovation and development of FEM (Finite element method) software the application of Cable stayed bridge has been promoted more. In the Recent Studies, Sam Li, a Senior Structural Engineering from Australia, gave a practical view on Static Analysis of Cable Stayed Bridges, which gave an illustration about the concept and design of bridges has been evolved over the past years, having numerous amounts of different geometrical models and methods to construct bridges. The Impact on Global Infrastructure by constructing a sustainable and aesthetical model of a cable stayed bridge has made a benchmark by its unique design properties. A cable stayed bridge can be built in different variations :

Corresponding author: priyanka24978@gmail.com 
- A side-spar cable-stayed bridge: has only one tower and is supported only on one side. One bridge built on this principle is bridge in Winnipeg, Manitoba, Canada and is made to carry pedestrians. Other is Jerusalem Chords Bridge which is also made to be curved which this design allows for.

- Cantilever-spar cable-stayed bridge has a single cantilever spar on one side of the span. Its spar is made to resist the bending caused by the cables because cable forces of this bridge are not balanced by opposing cables and bridge applies large overturning force on its foundation.

- Multiple-span cable-stayed bridge is a cablestayed bridge with more than 3 spans. It is a more complex bridge because the loads from the main spans are not anchored back near the end abutments. This also makes structure less stiff so additional design solutions

Extradosed bridge has stiffer and stronger deck and its cables are connected to the deck further from the towers which are also lower than those of standard cable-stayed bridges.

\subsection{Objective of the Study}

To evaluate current construction practices and assesses the data of the project sites and Assess information of the constructed cable stayed bridges by providing a detailed case studies for the bridges.

\subsection{The Scope of Study}

The study of cable stayed bridges shall be evaluated with the help of case studies of the following bridges

- Bandra Worli Sea Link

- Naini Bridge

- Vidhya Sagar Setu

- Hanging Bridge (Kota Bypass Chambal city) Signature Bridge, New Delhi

\subsection{Case Studies}

\subsubsection{Bandra Worli Sea Link}

Bandra Worli Sea Link (BWSL), also referred as Rajiv Gandhi Sea Link, is a cable stayed bridge located in Mumbai i.e. an eight-lane (two four lane highways) bridge. This bridge provisions 37,500 automobiles per day during traffic hours [7] and has the capacity to carry over 140,000 cars per day, providing a quicker alternative to the north-south traffic that presently amounted to 125,000 PCU per day. It is a connecting bridge linking the city with its western outskirts that showcases its potential to be a permanent solution to solve traffic patterns of the area [8]. The purpose of constructing the Bandra Worli Sea Link is primarily meant to provide as a solution to the Mahim Causeway route that served as the only connection between South Mumbai and the Western and Central suburbs. The project starts from the interchange at Mahim intersection of Western Express Highway and Swami Vivekanand
Road at the Bandra end and serves as a connection to Khan Abdul Gaffar Khan Road at the Worli end [9]. The BWSL commenced the construction from 2000, the project was serviceable to the public at $30^{\text {th }}$ June 2009 . The project was delayed numerous times due to many unsalaried payments and fishermen protests, which sums up to a total of INR 16.8 Billion project and was taken by Hindustan construction Company (HCC) to complete the project [10].

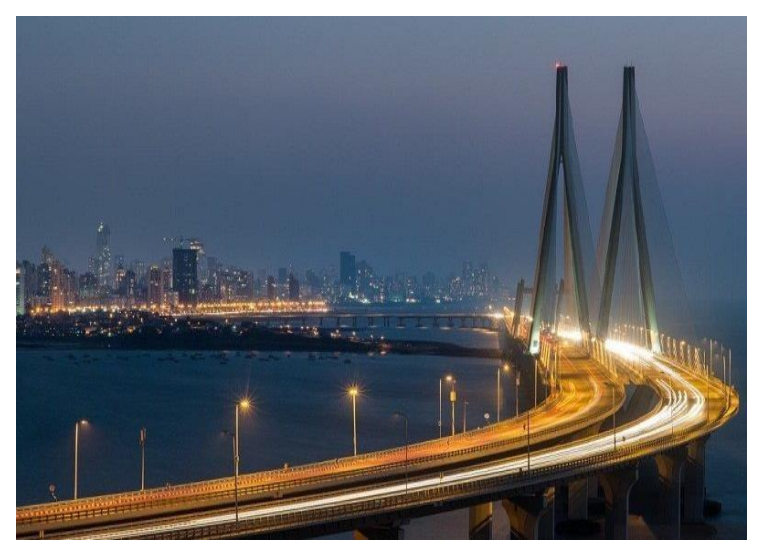

Fig. 1. Bandra-Worli Sea Link, 30th June 2009, Mumbai.

\section{Project Design}

The Bridge structure and salient features consists of [11- 15]:

The construction was carried out in five phases, called Packages, these packages provided with a systematic approach on dealing with the construction of BWSL. The first package dealt with the construction of a flyover over Love Grove junction that is in Worli. The second package consisted of constructing a cloverleaf interchange at the intersection of the Western express highway and connecting S.V. road in Bandra. The other packages involve a construction of a solid approach road from the Mahim intersection up to a start of the toll plaza which is located at the Bandra side and hosts a public promenade. The fourth and the most important package which would help in providing support to the main deck shall be the construction of central cable stayed spans with viaduct approaches starting from Worli to the Bandra end where toll plaza is located. Last package undergoes of improving the Khan Abdul Gaffar Road, which is still an ongoing process.

The main span is a total of $5600 \mathrm{~m}$ (sea link length), with main span being $4700 \mathrm{~m}$ and $3800 \mathrm{~m}$ being over sea. The pylon height boasts to 126 with $600 \mathrm{~m}$ long cablestayed bridge. Another cable stayed bridge situated at the Worli side with span $330 \mathrm{~m}$ long cable stayed bridge with tower heights being $54.779 \mathrm{~m}$ and $52.829 \mathrm{~m}$ is planned and constructed. An $811 \mathrm{~m}$ length bridge is linked with the Khan Abdul Ghaffar Khan Road situated on the Worli side. $800 \mathrm{~m}$ long precast segmental approach bridge is situated on the Bandra side. Along with the approach bridge, 16 lane toll plazas is also located on the Bandra side. The highlight feature during the construction process occurred after the use of polytron disc in bearing of piles for the first time in India. the BWSL bridge became the first project in Mumbai to use 
seismic arresters, which would aid the bridge to withstand earthquake up-to 7.0 on the Richter Scale [16].

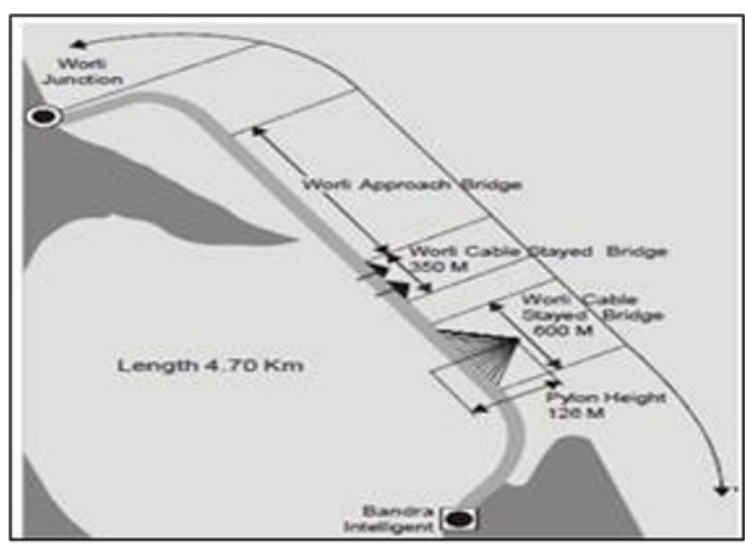

Fig. 2. Plan of the Bandra Worli bridge.

Table 1. Project Information.

\begin{tabular}{|c|c|c|}
\hline $\begin{array}{l}\text { S. } \\
\text { No. }\end{array}$ & Parameters & \\
\hline 1. & Concrete Poured & $2,30,000$ cu. m \\
\hline 2. & Reinforcement Steel used & 40,000 tons \\
\hline 3. & Length of wires used & $37,680 \mathrm{~km}$ \\
\hline 4. & Type of stay cables & Parallel wires \\
\hline 5. & Stay cable used & 1750 tons \\
\hline 6. & Precast segments & 2,342 Nos. \\
\hline 7. & Largest diameter piles & 604 Nos. \\
\hline 8. & Longest span & $500 \mathrm{~m}$ \\
\hline 9. & Total Length & $4700 \mathrm{~m}$ \\
\hline 10. & Weight & $6,70,000$ tons \\
\hline 11. & Width per carriageway & $18 \mathrm{~m}$ \\
\hline 12. & Height of Pylon & $126 \mathrm{~m}$ \\
\hline 13. & $\begin{array}{l}\text { Clearance below } \\
\text { Cable stayed sea link }\end{array}$ & $22 \mathrm{~m}$ \\
\hline 14. & Type of foundation & 130 concrete piles \\
\hline
\end{tabular}

Traffic Volume

Bandra Worli Sea link has been designed and planned to serve as an alternative to the Mahim Causeway route. This bridge provisions 37,500 automobiles per day during traffic hours and has the capacity to carry over 140,000 cars per day, providing a quicker alternative to the north-south traffic that presently amounted to 125,000 PCU per day. It is a connecting bridge linking the city with its western outskirts that showcases its potential to be a permanent solution to solve traffic patterns of the area $[7,8]$.

Time Saved

This huge project will save the time between Bandra and Worli from 45 minutes to 6 minutes. the bridge is a total of $5.6 \mathrm{~km}$ long compared to the old route from Mahim Causeway route which is $8 \mathrm{~km}$. it saves the consumer from 29 traffic lights [17]
Table 2. Traffic Volume and Time Saved [18].

\begin{tabular}{|c|c|c|c|}
\hline $\begin{array}{c}\text { S. } \\
\text { No. }\end{array}$ & Parameters & $\begin{array}{c}\text { Before } \\
\text { BWSL }\end{array}$ & $\begin{array}{c}\text { After } \\
\text { BWSL }\end{array}$ \\
\hline $\mathbf{1 .}$ & $\begin{array}{c}\text { Distance between South Mumbai- } \\
\text { Western suburbs }\end{array}$ & $7.7 \mathrm{~km}$ & $4.70 \mathrm{~km}$ \\
\hline $\mathbf{2 .}$ & Traffic Signals & 23 & 4 \\
\hline 3. & Morning Peak Hours to travel & $35 \mathrm{~min}$. & $6 \mathrm{~min}$. \\
\hline 4. & Average Journey Speed & $13 \mathrm{kmph}$ & $80 \mathrm{kmph}$ \\
\hline
\end{tabular}

Economic Internal Rate of Return

The BWSL charges a one-way trip from the constructed toll Plaza as ₹70 daily pass will be taken out by the Maharashtra State road Development Corporations. The monthly pass was carried out at ₹3500 for the regular users. [19].

Table 3. Toll Plaza Rate of monthly pass [20].

\begin{tabular}{|l|l|l|l|l|}
\hline S. No. & Vehicles & $\begin{array}{l}\text { Monthly } \\
\text { Pass }\end{array}$ & $\begin{array}{l}\text { 50 Single } \\
\text { Journey (10\% } \\
\text { Discount) }\end{array}$ & $\begin{array}{l}\mathbf{1 0 0} \\
\text { Single } \\
\text { Journey }(\mathbf{2 0} \% \\
\text { Discount) }\end{array}$ \\
\hline 1. & $\begin{array}{l}\text { Car, Jeep, } \\
\text { Tata } \\
\text { Sumo }\end{array}$ & $3,500 /-$ & $3150 /-$ & $5600 /-$ \\
\hline 2. & $\begin{array}{l}\text { Mini-Bus, } \\
\text { LCV }\end{array}$ & $5500 /-$ & $4950 /-$ & $8800 /-$ \\
\hline 3. & Truck, Bus & $7250 /-$ & $6525 /-$ & $11600 /-$ \\
\hline
\end{tabular}

Table 4. Toll Plaza Rate [20].

\begin{tabular}{|c|c|c|c|c|}
\hline S. No. & Vehicles & $\begin{array}{l}\text { Rate of Toll } \\
\text { in Rupees } \\
\text { Single Trip }\end{array}$ & \begin{tabular}{|l|} 
Return \\
Rate \\
Troll \\
Rupees \\
Trip \\
\end{tabular} & \begin{tabular}{l|l} 
Daily Pass \\
of \\
in $\mid$ Trote of \\
per \\
Rupees \\
per trip
\end{tabular} \\
\hline 1. & $\begin{array}{l}\text { Car, Jeep, Tata } \\
\text { Sumo }\end{array}$ & $70 /-$ & $105 /-$ & $175 /-$ \\
\hline 2. & $\begin{array}{l}\text { Mini-Bus, } \\
\text { LCV }\end{array}$ & $110 /-$ & $165 /-$ & $275 /-$ \\
\hline 3. & Truck, Bus & $145 /-$ & $215 /-$ & $360 /-$ \\
\hline
\end{tabular}

Impact on Employment creation

About 2,850 workers were supervised by 150 engineers to work on the BWSL project and were employed for over a span of eight years contributing 25.7 million manhours between the span of 2001 and 2009 [21]

Impact on Environment

Savings in fuel and vehicle has estimated to be operating of cost 1000 million per annum and considerable savings in time traveling from $35 \mathrm{~min}$. to 5 min. due to increase in speed has resulted in reduction of traffic and noise pollution. A decline in carbon monoxide and nitrogen oxide levels has also occurred [22].

\subsubsection{Naina Bridge}

Yamuna Bridge located in Prayagraj which was initiated by the Allahabad District as it is surrounded by the Yamuna and Ganges rivers to the north, east and south, hence the bridge's name is followed up by Yamuna Bridge. Any further requirement for development were 
restricted due to the urban area being densely populated with residents. The adjacent Naini District across the River Yamuna served as an industrial center where communication, automobile, fertilizer, textile, and industry companies are located [23]. The only traffic route connecting these two districts was the existing bridge over the River Yamuna. Due to poor maintenance and an outdated design, the authorities initiated the construction of Naini Bridge or New Yamuna Bridge which would be a four-lane bridge to replace the existing old two-lane bridge across the River Yamuna connecting the Allahabad District and the Naini District of Allahabad, Uttar Pradesh State, for the purposes of declining traffic congestion. The traffic which would be able to flow smoothly and at the same time improve the national highway network by connecting National Highway 2 and National Highway 27, thereby helping invigorate the regional economy [24].

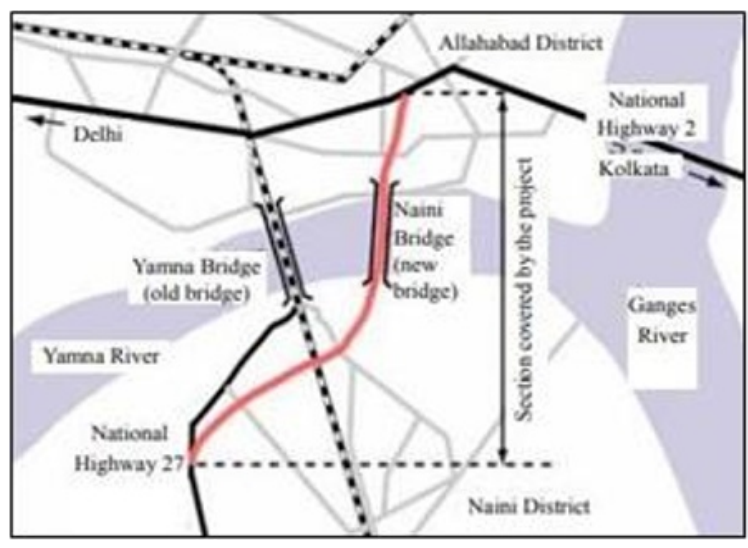

Fig. 3. Project Area of Naini Bridge.

Project Design

The Bridge structure and salient features consists of [25- 29]:

The project period was scheduled from January 1994 to July 2004, out of which the delay in project execution occurred is of four years and four months longer than the planned period which was planned as from January 1994 to March 2000. Apart of the delay the bridge consisted of pylons of height $90 \mathrm{~m}$ which are supported on $40 \mathrm{~m}$ deep open dredged well foundations. The total length of the bridge is $1510 \mathrm{~m}$ long with the main span being 260 meter and side span being $115 \mathrm{~m}$. The total length is 610 $\mathrm{m}$ with $490 \mathrm{~m}$ long span of cable state bridge the deck width is about 26 meter and the approach bridges are $365 \mathrm{~m}$ long.

Project Information
Table 5. Project Information.

\begin{tabular}{|l|l|c|}
\hline $\begin{array}{l}\text { S. } \\
\text { No. }\end{array}$ & Parameters & \\
\hline $\mathbf{1 .}$ & Concrete Poured & $53,000 \mathrm{cu} . \mathrm{m}$ \\
\hline $\mathbf{2 .}$ & TMT Steel used & $3000 \mathrm{mt}$. \\
\hline $\mathbf{3 .}$ & Super structure steel & $9100 \mathrm{mt}$. \\
\hline $\mathbf{4 .}$ & Total Length & $1,510 \mathrm{~m}$ \\
\hline $\mathbf{5 .}$ & Height of Pylon & $90 \mathrm{~m}$ \\
\hline $\mathbf{6 .}$ & Girder Depth & $1.4 \mathrm{~m}$ \\
\hline $\mathbf{7 .}$ & Deck Width & $26 \mathrm{~m}$ \\
\hline $\mathbf{8 .}$ & Approach Bridges & $365 \mathrm{~m}$ \\
\hline $\mathbf{9 .}$ & Length of Bridge & 1034 Rmt. \\
\hline $\mathbf{1 0 .}$ & Type of Foundation & $\begin{array}{c}\text { Deep open dredged } \\
\text { Well Foundation }\end{array}$ \\
\hline
\end{tabular}

Traffic Volume

The traffic volume compared to the older Yamuna Bridge with the Naini bridge gave an increase in the PCU, also helped in terms of time saving as the distance which was used to cover a distance in $35 \mathrm{~min}$. is now able to covered in $5 \mathrm{~min}$. [26]. Given table has shown the increase in the number of traffic volume as the data shows an average of 7,115 vehicles/day in 1990 to an increase in traffic volume of 15,700 vehicles/day.

Table 6. Traffic Volume and Time Saved Data [26].

\begin{tabular}{|c|c|c|}
\hline Passenger & $\mathbf{1 9 9 0}$ & $\mathbf{2 0 0 6}$ \\
\hline Car & 5,168 & 14,342 \\
\hline Bus & 1,436 & 1,148 \\
\hline Truck & 3,968 & 5,275 \\
\hline Total & 8,568 & 20,765 \\
\hline
\end{tabular}

Time Saved

Table 7. Traffic Volume and Time Saved.

\begin{tabular}{|c|c|l|c|}
\hline Section & Kilometer & $\begin{array}{l}\text { Before Project } \\
\text { (Yamuna } \\
\text { Bridge) }\end{array}$ & $\begin{array}{c}\text { After Project } \\
\text { (Naini Bridge) }\end{array}$ \\
\hline $\begin{array}{l}\text { Allahabad- } \\
\text { Naini }\end{array}$ & 4.7 & $\begin{array}{l}32 \text { min. } \\
\text { (Average) }\end{array}$ & $5 \mathrm{~min}$, \\
\hline Congestion & & 35 min. & 0 min. \\
\hline
\end{tabular}

Economic Internal Rate of Return

Table 8. Toll and Operation and Maintenance status [30].

\begin{tabular}{|l|c|c|c|}
\hline & 2003-04 & 2004-05 & 2005-06 \\
\hline Toll Revenue & 3,594 & 4,605 & 7,980 \\
\hline $\begin{array}{l}\text { O\&M } \\
\begin{array}{l}\text { Operation and } \\
\text { Maintenance } \\
\text { status) }\end{array}\end{array}$ & 2,752 & 2,786 & 2,448 \\
\hline
\end{tabular}

Impact on Employment creation

During the implementation phase of the project, many local people were employed for construction and other works, thus the project is considered to have a certain impact on employment creation in the short term.

Impact on Environment

A survey suggested that air pollution, noise pollution improved significantly after the project. The rate of those who favored for improved situation were $63 \%$ for air pollution, $50 \%$ for noise. Smooth traffic resulted in less noise pollution [31]. 


\subsubsection{Pandit Dindayal Upadhyay Cable Stay Bridge}

Project Information

Table 9. Project Information.

\begin{tabular}{|c|c|c|}
\hline $\begin{array}{l}\text { S. } \\
\text { No. }\end{array}$ & Parameters & \\
\hline 1. & Number of spans & 15 Nos. \\
\hline 2. & Total Length & $918 \mathrm{~m}$ \\
\hline 3. & Weight & $6,70,000$ tons \\
\hline 4. & Carriageway & $\begin{array}{c}7.50 \mathrm{mt} .+7.50 \\
\text { mt. (Two Lane up } \\
\& \text { Two } \\
\text { Lane Down) }\end{array}$ \\
\hline 5. & Height of Pylon & $35 \mathrm{~m}$ \\
\hline 6. & Approach Length & $\begin{array}{c}122.25 \mathrm{~m} \\
\text { (Athwa- side) } \\
84.33 \mathrm{~m} \\
\text { (Adajan-side) } \\
\end{array}$ \\
\hline 7. & Type of Foundation & Pile Foundation \\
\hline
\end{tabular}

Pandit Dindayal Upadhyay Cable Stay Bridge project title is Cable Stayed Bridge in Coastal Zone of Tapi River Joining Adajan and Athwalines Area of Surat, Gujarat, started in 2010 and has been finalized in 2018 by the S.N. Bhobe and Associates [32] and later were assigned to Casad Consultant, Ahmedabad due to failure of slab accident [33]. As the project title suggests, this cable stayed bridge was designed to connect with a three-way interchange flyover bridge that was connected to the Athwa side of the main river bridge. Surat Municipal Corporation tries to improve road infrastructure of the city which Owed itself to heavy traffic congestion on major highways situated in Surat city, the BRTS (Bus Rapid Transit System in Surat) system work has been initiated in most of the area [34]. The major highways passing through Surat are the Udhana-Mumbai Highway also known as UdhanaNavsari Highway, Surat-Ahmedabad Highway also known as Varachha Main Road [35]. To combat fatal accidents, Surat Municipal Corporation and Surat Urban Development Authority has developed an Outer Ring Road and Middle Ring Road to decongest the traffic from the major highways passing through the city [36]. The city has seen the completion of road projects, particularly elevated roads. With growing industrialization and increasing of population in the city, the Surat Municipal Corporation has proposed to construct first cable stayed bridge over Tapi river to facilitate the smooth passage between Adajan to Parle point near Athwalines accounting about 1436.5 million INR. Which opened for public at $2^{\text {nd }}$ October 2018 [37].

Project Design

The Bridge structure and salient features consists of [38- 40]:

The Pylon height consisted of $35 \mathrm{~m}$ and were two in the bridge of total length $918.21 \mathrm{~m}$. The bridge is a Highlevel cable stayed bridge and the length of the cable stayed bridge is $300 \mathrm{~m}$. Surat Municipal Corporation has proposed to construct the bridge in coastal zone of Tapi river joining Adajan and Athwalines area of the Surat city. The bridge is cable Stayed type bridge in main river course and PSC type of simply supported bridge in rest of the portion with solid ramps on either side. The design is based on relevant IRC code of practice and MORTH Specification applicable to industrial practice. The foundation consists of a pile foundation, i.e. adopted for Pylon, Pier, Abutment \& Vented span of the approach portion. Open foundation is adopted for retaining wall in the project. As per the CRZ notification of construction of proposed Cable Stayed Bridge in Coastal Zone of Tapi River joining Adajan and Athwalines area, Surat falls in CRZ area.

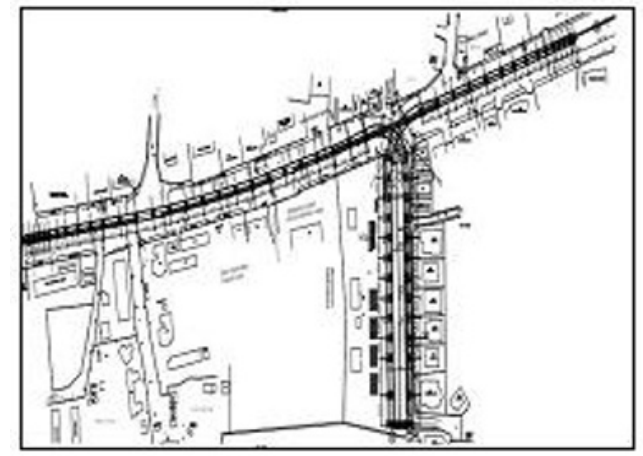

Fig. 4. Project layout of Pandit Dindayal bridge.

\subsubsection{Signature Bridge, New Delhi}

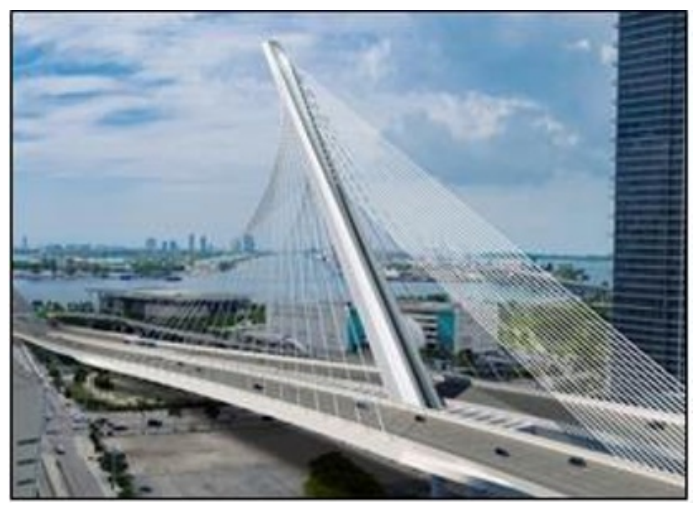

Fig. 5. Signature Bridge, 4th Nov 2018, New Delhi.

Table 10. Fact File of Signature Bridge.

\begin{tabular}{|l|c|}
\hline Location of the Project & Wazirabad, New Delhi, India \\
\hline Client & $\begin{array}{c}\text { DTTDC (Delhi Tourism \& } \\
\text { Transport Development } \\
\text { Commission) }\end{array}$ \\
\hline Designer & $\begin{array}{c}\text { Schlaich Bergermann \& Partner, } \\
\text { Germany in JV with Construma } \\
\text { Consultant Pvt. Ltd } \\
\text { (CCPL) Mumbai }\end{array}$ \\
\hline Architectural Advisor & $\begin{array}{c}\text { Ratan J. Batliboi- Architects Pvt } \\
\text { Ltd, } \\
\text { Mumbai }\end{array}$ \\
\hline Ceismic Studies & IIT Roorkee \\
\hline Checking Engineer & $\begin{array}{c}\text { Syntra and M. Virlogeux, France } \\
\text { associated with Tondon } \\
\text { Consultants, New } \\
\text { Delhi }\end{array}$ \\
\hline Construction/ Contractor & Gammon C. Cidade Tensacciai JV \\
\hline
\end{tabular}

The Signature bridge located in Northern-Eastern part of Delhi, has become a new milestone for Delhi 
Tourism \& Transport Development Corporation which connects Wazirabad city across the Yamuna to the inner city [41]. This bridge was planned by the Delhi Govt. during the common wealth games to become Delhi's new tourist attraction. The project was divided into two parts, first part of the project was to build a bridge over the Yamuna connecting parts of North and East of Delhi, the other part was to develop a park around the bridge. Due to the lack of road infrastructure between the regions, the bridge was planned to divert the heavy traffic loads along Marginal Bund Road at Khajuri Khas on the eastern bank and Wazirabad the western bank of river Yamuna considering the population rise in Trans Yamuna Area. [42] The Special Feature of this cable stayed bridge is the dynamic shape of the designed inclined pylon consisting of two major columns which merges at the upper pylon section, rigidly connected to bend mid-way and driving lanes. The Influential feature of the pylon is that the Self- Weight of pylon of the bridge compensates the dead load of main span through eccentric location of its centre of gravity with respect to the pivot point of the pylon footing. Another main striking feature of the signature bridge is tip head of the pylon which is developed as high steel-glass structure of 30 meters. The Upper section of pylon helps to anchor the main span cables as well as backstay cables which designed in a harp like structure, this distributes well which reduces the load on the back-stay cables. The bridge has become an engineering masterpiece consisting of 8 lanes (4 lanes for each direction) having 2-meter-wide side verges, space for maintenance walkway, for cable anchorage as well as the crash barriers built on the either side of the deck. [43] The signature bridge is a combination of steel tower and composite deck which are supported by series of well and open foundation. The design of Yamuna bridge is a well grated combination of robustness and structural sanity with the demand of the signature bridge. The Deck supported with cables of span 251 meters overpassing the space for future lake without supports to the ground, the section of the deck is supported with the piers at fixed intervals of 36 meters. After evaluating all the geometrical designs and observing all the site behaviors, cable stayed bridge model was proposed and accepted due to the novel features as it is easily identifiable and provides it with signature appearance along with that the use of slender composite deck which is a well proven structural solution inspired by the Second Hooghly Bridge in Kolkata. The Structural Design of the bridge were approved by Delhi Govt. and the Delhi Urban Art Commission but there was a demand of a long span and light weight bridge by DTTDC (Delhi Tourism and Transport Development Corporation) as River Yamuna displays lake like dimensions. In the conceptual design, the upper section of the pylon is constructed by steel-glass structure which gives a platform at the pylon head for inspection purposes also can be used for viewing purposes. The steel-glass pylon lights up in nights which converts the pylon into beacon that can be seen from a long distance along with that Indian Ornament graphics are used to increases its attraction.

\section{Structural Design}

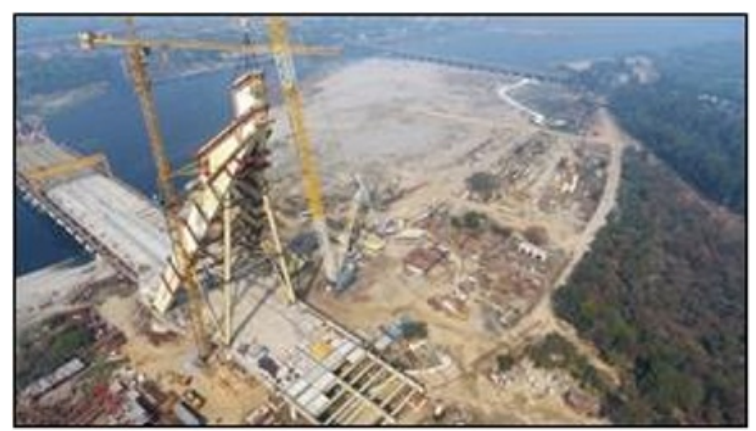

Fig. 6. Construction of Signature bridge.

Table 11. Structural Details.

\begin{tabular}{|l|c|}
\hline Main Span & \multicolumn{1}{|c|}{251 meters } \\
\hline Total Length of the Bridge & $\begin{array}{l}\text { 675 meters incl. } 100 \mathrm{~m} \\
\text { western extension. }\end{array}$ \\
\hline Number of Lanes & 8 Lanes (4 on each direction) \\
\hline Width of the Deck & 35 Meters approx. \\
\hline $\begin{array}{l}\text { Space between two consecutive } \\
\text { stay cables }\end{array}$ & 13.5 meters \\
\hline Height of Pylon & 165 meters above the ground \\
\hline Deck Surface & $25000 \mathrm{~m}^{\wedge} 2$ \\
\hline Structural Steel Pylon & 5800 tonnes \\
\hline Structural Steel Deck & 7400 tonnes \\
\hline Number of Open Foundation & 6 Nos. \\
\hline Number of Close Foundation & 16 Nos. \\
\hline
\end{tabular}

Deck

The Deck is Developed with two carriageways, made with concrete of 14 meters wide along with crash barriers on both the sides of the deck and lateral emergency pathways which combines together to form a deck to total length of 32.5 meters. The third main central girder is provided to distribute loads coming from heavy vehicles onto the several main girders. The composite deck offers economic improvement of having concrete balancing the cable thrusts horizontally, costfree prestress along with that it also provides simple and quick erection. The deck is supported transversely on the both the ends of the bridge and deck is only longitudinally supported at the pylon. it has been observed that the movement in longitudinal direction at the western end is approx. $250 \mathrm{~mm}$.

Table 12. Description of Deck.

\begin{tabular}{|l|l|}
\hline Total Width of Deck & 32.5 meters \\
\hline Number of Lanes & $\begin{array}{l}\text { Each Carriageway contains 4 } \\
\text { traffic lanes }\end{array}$ \\
\hline $\begin{array}{l}\text { Shape of Longitudinal Main } \\
\text { Girder }\end{array}$ & \multicolumn{1}{|c|}{ I - Shape } \\
\hline I-Shaped Cross girders & 4.5-meter Interval \\
\hline Structural Steel grade & S355 (or Indian Equivalent) \\
\hline Precast Deck Slab & $\begin{array}{l}\text { M50 grade of Concrete span 4.5 } \\
\text { meters }\end{array}$ \\
\hline
\end{tabular}




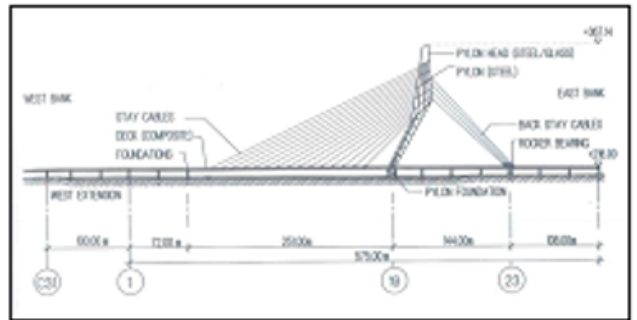

Fig. 7. Girder cross sectional area.

\section{Stay Cable}

Two cable planes support the deck of the bridge, these stay cables are anchored directly to outer main girder web at 13.5-meter distance with their dead ends, are stressed within the stressing chamber at the top of the pylon. The cables are made of bundles of parallel 0.6 " strands, to provide the corrosion protection layer each strand is coated that are covered with an outer PE Pipe along with hot dip of galvanized wires. For Fire Protection, cables at lower part of backstay area are covered with steel tubes.

Pylon

The pylons of the bridge are two inclined columns which is created by steel boxes, as the pylon moves above the deck, the upper section of pylon merges together as one pylon zone, where cables are supported with main span, the backstay cables are anchored \& interconnected. The upper section of pylon is designed as hollow steel box section. The deck is monolithically connected by pylons, introduces horizontal forces in the longitudinal direction into the concrete of the deck. The horizontal forces in transverse direction are taken by strong steel cross girder that connects two legs at the level of the cross girder.

The pot bearings are introduced to support the pylon leg placed below the deck which will resist the bending of the substructure.

The Upper section of pylon rise further approx 20 meters from the top most anchorage developing the pylon head of steel-glass structure.

High level of floods is expected during monsoon (HFL 210 meters approx. and the deck level of the signature bridge is 216 meters.

Table 13. Description of Cables.

\begin{tabular}{|l|l|}
\hline Grade of strand & 1770 \\
\hline Number of stay cables & Varies from 55 to 123 Nos. \\
\hline Stay cables at main span & $\begin{array}{l}127 \text { Nos. for each backstay } \\
\text { cable }\end{array}$ \\
\hline
\end{tabular}

Table 14. Description of Pylon.

\begin{tabular}{|l|l|}
\hline Height of Pylon & 165 meters above the ground \\
\hline forces & \multicolumn{1}{|c|}{$170 \mathrm{KN}$} \\
\hline Grade of Steel & $\begin{array}{l}\text { S355 grade is used in major parts } \\
\text { of pylon In High stress zones, such } \\
\text { as bent portion of pylon Grade of } \\
\text { Steel used is S460 }\end{array}$ \\
\hline
\end{tabular}

Note: For which Indian codes are not available, Euro Codes were used.
Foundation

As the Design is complex and unique due to its structure, Some Foundation are designed with high horizontal forces and some foundations are designed with high uplift forces. For the bridge the foundations are laid as 6 open foundations and 16 well foundations, out of which 8 well foundations are on alluvial soil and balanced on the undulated rock both in longitudinal and transverse direction. Due to high scour levels and seismic events liquification of soil has been considered while designing the foundation of the bridge.

From Economical aspect, Jack down method is used for developing all the well foundations which helped in saving concrete and steel quantity. The method also maintains in complete controlling of well sinking which helps to resist tilting and shifting which also includes the situation of stuck of well on stiff clay. The inspiration for the foundation of the bridge was taken from second Hooghly bridge and Varanasi Bridge.

Table 15. Details of Foundation.

\begin{tabular}{|l|c|}
\hline Open Foundations & \multicolumn{1}{|c|}{ 6 Nos. } \\
\hline Well Foundations & 17 Nos. \\
\hline $\begin{array}{l}\text { Main Scour Level for flood } \\
\text { check }\end{array}$ & 182 meters \\
\hline $\begin{array}{l}\text { Normal flood level } \\
\text { considered for seismic case }\end{array}$ & $\begin{array}{l}\text { Varies from 173 meters to 193 } \\
\text { meters. }\end{array}$ \\
\hline Rock Level & 1770 \\
\hline Grade of strand & Varies from 55 to 123 Nos. \\
\hline Number of stay cables & 127 Nos. for each backstay cable \\
\hline Stay cables at main span
\end{tabular}

Deck erection support which should resist bridge. A $3 \mathrm{~d}$ finite element model of the bridge was developed for global analysis. Deck was modelled using the shell element for concrete slabs which are rigidly connected to beam element, the deck was designed as to withstand the failure of any one cable \& its load case that often rules the design. For pylon, 3-D shell element method was considered. Second order effect was considered by geometrical non- linear algorithm was applied to predeformed system. All the analysis done on computer is only made for conventional approximation, not consider for design purposes only for comparisons and checks.

Three Methods were used for analyzing extensive seismic designs:

- Equivalent Static Method

- Response Spectrum Method

- Linear Time History Analysis.

All the methods were used to analysis the seismic design of the bridge structure which concluded that seismic forces with uniform lateral load of $10 \%$ of gravity are on safer side. The Wind load test was performed by wind tunnel method which proved that flutter is not an issue, the Average transverse wind load that was applied to pylon was $1.7 \mathrm{KN} / \mathrm{m}^{\wedge} 2$. Local peak loads for glass design at tip of the pylon are up to 4.2 $\mathrm{KN} / \mathrm{m}^{\wedge} 2$. [43]

Erection

Earlier, it was decided that free cantilever erections for cable stayed bridge will not be consider as there was 
no lake present then, instead the development and construction of the deck was made on temporary support, the

\subsubsection{Kota-Chambal Bridge}

Kota-Chambal Cable Stayed Bridge more acknowledged as Kota Hanging Bridge, is one of the largest Cable stayed bridges in India with main span of 350 meters over the river Chambal, it is the first axial suspension cable stayed bridge in India [44]. National Highway Authority of India (NHAI) planned to construct a cable stayed bridge connecting Chambal on NH-76 without disturbing its wildlife by avoid placing any pier in the river bed [45]. The project was a joint venture lead by Hyundai Engineering and Gammon India with the estimated cost of 277.67 crores (INR) [44].

The Construction of the Project was started in late 2006 with the estimation of completion within 10 years. Further the Project was hauled due to the collapse of a pier in December,2009. The project restarted years later and in 2017, the bridge was open for public use [44].

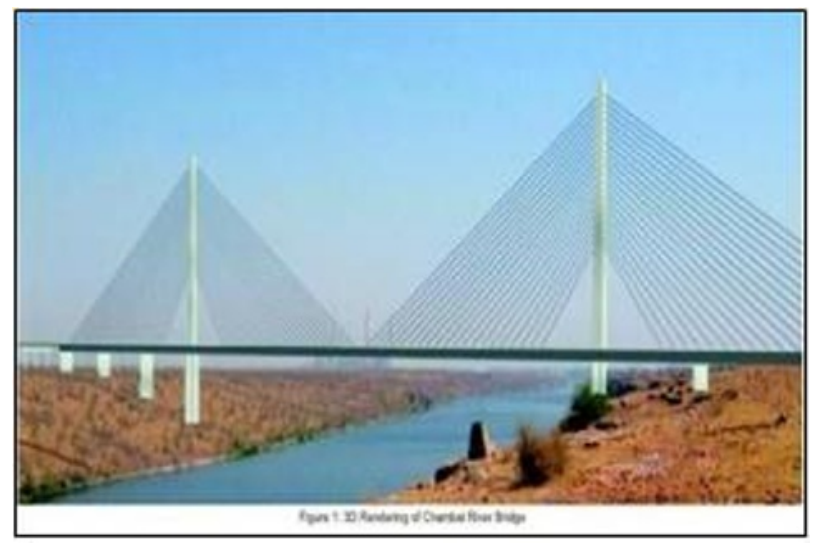

Fig. 8. Kota Chambal Bridge.

\section{Project Description}

The Bridge consists of a 6-lane carriageway with 3meter central media with two footpaths of each 1.5meter width located on the deck side. the Individual deck consisted in a single cell box girder of 30 meters reinforced at every 3.5 meters by transverse ribs. The deck is withstanding by installing pot bearings in all the piers except for the shortest pylon which is rigidly connected.

The special investigation has been done for the piers located at the cliff, as there is a need to study geotechnical and geophysics investigation for understanding cliff stability. the better quality of rock on which all the piers are laid upon.

The structural members will be constructed on site by using cantilever method for the main span and scaffoldings for the lateral span. [45]

Site Investigation

The topographical investigation consists of a survey concerned about the ground position, this was performed to determine the position of piers, localize the bridge axis and determine ground level at foundation location which also concluded that there is no major topography abnormality on site. The survey helped in creating a $3 d$ image of a cliff to understand the accuracy of cliff stability due to the pylons (p5) is located just 30 meters away from the edge of the cliff.

The Geotechnical Investigation was done in three different ways, geophysical survey, site investigation and satellite imagery.

The Site Investigation consists of various in-setu and laboratory tests which was done to ensure the properties of the soil. The onsite test contains permeability test, $\mathrm{CaCo} 3$ Content and Visual Identification and the Laboratory Test such as Dry density test, water absorption test, specific gravity, point load index (PLI) test, resistance test (uniaxial compressive strength), Elastic Modulus and Poisson's Ratio.

The result of these test was concluded as following:

- The soil component is mainly consisting of hard siliceous sandstones, due to the change in temperature metamorphism takes places on 10 first meters which increases the amount of silica, which turns sandstones into quartzite.

- CaCo3 Test shows that there is absence of calcium carbonate in the samples and the Uniaxial compressive strength of rocks are in between 100-300mpa.

- Young's Modulus $=17500 \mathrm{mpa}$ for intact rock.

- Poisson's ratio= 0.21

- Absence of aggressive elements which could affect the stability and durability of the structure.

Geophysical Investigation

It shows the cross-hole test done at the location of pylons which confirms the existence of weak rock at the depth of 13 meters and the absence of cavities and channels below the ground level with no other major variation and the presence of weak rock is not exceeded up to the cliff edge which does not affect the stability of the cliff.

Satellite Imagery

This investigation concludes that there is no cavity below the water level which could exceed below pylon (p5).

\section{Foundation}

The Foundation of Pylons of the bridge consists of two vertical shafts with the maximum length of 15 meters and diameter of 4.5 meters. The piers of the bridge are supported by the rectangular footing, further the bearing parameters are followed by AASHTO LRFD code for rock mass ratio classification. The grade of concrete in all the foundations is M47.5 and the pile caps are placed above the vertical shafts with the depth of 2 meter to 5 meters (extremities) at pier axis. For Future Reference, empty ducts are kept for new active anchors if needed. [45]

Sub-Substructures

The main load comes from the pylon so it is advisable to place some material below the rectangular axial pylon and other loads induces from deck web and its diaphragm also advisable to place some material below the diaphragm, this explains the cross shape of the pylon's pier.[45] 
Table 16. Description of Substructure.

\begin{tabular}{|l|l|}
\hline Lateral piers & Rectangular Shape \\
\hline Pylon Piers & Cross shape \\
\hline Pier (p5) & Rigidly Connected to deck \\
\hline Pier (p4) & $\begin{array}{l}\text { Has a pier cap supporting 4 } \\
\text { spherical bearings of each } \\
\text { 7000 Tons }\end{array}$ \\
\hline
\end{tabular}

Seismic Design

The design was made as per the provision of IS 1893: 1962 (2002 Revised), the city of Kota falls under the seismic zone II with the ground acceleration of 0.1 along the gravitation acceleration. The earthquake load was designed for the service stage of the bridge and also for the worst construction stage, Response modification factor was considered as per AASHTO LRFD code. A $3 \mathrm{~d}$ model was developed to calculated all the earthquake forces acting upon the bridge including the parts of access bridges for accurate effect on transition pier.[45]

Bearings

Pot bearings are supported at the lateral spans with the maximum vertical capacity of 1200 tons at service stage, also these bearings can resist the uplifted forces calculated for maximum of 380 tons at strength limit state.

Pylon

To place the anchorage of stay cables, steel frames were provided in pylon. There are 20 steel frames provided in pylon to take horizontal components of stay cables and the pylon transmits vertical components through shear studs placed at lateral sides of the steel boxes. With the help of buckling analysis, dynamic wind load has been verified for structural resistance of pylons. [45]

Table 17. Description of Pylon.

\begin{tabular}{|l|l|}
\hline Hight of pylon & 80 meters from top of the deck \\
\hline Width & 3 meters \\
\hline Length & From 7 to 4 meters (Variable) \\
\hline Grade of Concrete & M60 \\
\hline Manhole in Pylon & $800 * 1500 \mathrm{~mm}$ (inside the pylon) \\
\hline
\end{tabular}

Stay Cables

The Stay cables consists of sheathed strands with triple layer protection: Galvanization, polyethylene sheaths and wax filling. Helicoids shape for external ducts to protect from rain and induced vibrations. For longest stay cables, anti-vibrational devices have been installed. Each Strand- 7 wires of $1860 \mathrm{mpa}$ each and stay cable unities from 58 to 91 strands. [45]

Deck

Box girders are filled with concrete to reduce the uplifted forces on the lateral pier, to generate prestressed layout and its accessibility, complete 3D AUTOCAD model of cable stayed bridge was developed. Also, 3d model can be helpful in reinforcement shop drawings.
Table 18. Description of Deck.

\begin{tabular}{|l|c|}
\hline Grade of Concrete & M60 \\
\hline Prestressing in concrete & $\begin{array}{l}\text { Use of External and Internal Tendons } \\
\text { for Longitudinal and Use } \\
\text { Internal Tendon only for Transverse }\end{array}$ \\
\hline $\begin{array}{l}\text { Transverse Prestressing } \\
\text { in ribs }\end{array}$ & $13 T 15$ tendons \\
\hline $\begin{array}{l}\text { Transverse Prestressing } \\
\text { in slab }\end{array}$ & $4 \mathrm{~T} 15$ tendons \\
\hline Transverse Analysis & $1 / 3^{\text {rd }}$ of Bridge using Finite Elements \\
\hline
\end{tabular}

Serviceability of Cable Stayed Bridge

The Structure obtained to reduce the immense traffic load of vehicles passing to NH-52 to Jhalawar \& NH-27 to Baran, helped to facilitate the swift movement of the vehicles. With the increase in the number of vehicles the $\mathrm{CO} 2$ concentration in the air is expected to $450 \mathrm{ppm}$, estimated service design life of the structure was deprived by using PAPADAKIS \& Al. Model.

The Estimation of service life of a structure is expressed as time required for carbonation to reach the first layer of reinforcement, based on the features of the bridge such as deck box girder of $40 \mathrm{~mm}$ and external concrete cover for pylons has helped to achieve 100 years of serviceability design life. [45]

\subsubsection{Vidyasagar Setu Cable Stayed Bridge}

Vidyasagar Setu is the longest constructed cable stayed bridge in India connecting the cities of Kolkata and Howrah, West Bengal. It is also named as Second Hooghly Bridge and is one of longest bridges in Asia. With a total length of $822.96 \mathrm{~m}$, width of $35 \mathrm{~m}$ and the longest span of $457.2 \mathrm{~m}$, it was the second bridge constructed across the Hooghly river, after the first Howrah Bridge, Rabindra Setu was built. It was named after the 19th-century Bengali educationist reformer Pandit Ishwar Chandra Vidyasagar and was the collected efforts of both the public and the private sectors.[46]

The bridge was constructed by The Braithwaite Burn and Jessop Construction Company Limited and is maintained by Hooghly River Bridge Commissioners (HRBC). Schlaich Bergermann \& Partner designed the bridge, and it was examined by Freeman Fox \& Partners $\&$ Bharat Bhari Udyod Nigam Limited. On $20^{\text {th }}$ May 1972 , the foundation stone for the project was placed by Indira Gandhi, the construction of the bridge began on $3^{\text {rd }}$ July 1979 and was opened to traffic on $10^{\text {th }}$ October 1992.[46]

Architectural Features

Vidyasagar Setu is a cable stayed bridge, supported with 121 cables and constructed using steel pylons of $127.62 \mathrm{~m}$ in height. The deck of the bridge consists of dual carriageways that is made up of composite steelreinforced concrete. The main span of the deck is $457.20 \mathrm{~m}$ long and the side spans are $182.88 \mathrm{~m}$ long those are assisted by parallel wire cables. The total width of the bridge is divided into three lanes in each direction along with wide range footpath on each side. The traffic bearing capacity is more than 85000 vehicles per day but the bridge is used by around 30,000 vehicles per day. 
The Vidyasagar Setu is a toll bridge provided with the free lanes for the bicycles.[47]

Project Design

The design of Vidyasagar Setu is different from other bridges, those are of live load composite construction. It differs from the concept of dead load adopted for designing of this type of bridge and concreting provided by intermediate trestle for the side spans of the bridge. Designing of deck is done by the grid structures of girders, such that a set of girders is provided at the end and the other set is provided in the middle. It is supported by girders those are spaced approximately at distance of $4.2 \mathrm{~m}$ (14ft) Centre to Centre. For the construction of the main span of the bridge, a deck crane was used and for erecting the pylons of the bridge, a deck crane with the capacity of 45 tones was used.

The structural steel used for the construction of the Vidyasagar Setu bridge weighs near about 13,200 tones. The designing of free-standing portals is done with the pylons those are $128 \mathrm{~m}$ in height. They are supported by two cross portal members below the pylon head, such that one is below and other is at the top. The deck is linked to the end piers with the bolds inserted in the chambers of piers. The pylons built from $4 \mathrm{mx} 4 \mathrm{~m}$ steel boxes of riveted construction were installed on both the sides the bridge, each set on the Calcutta side and Howrah side of the bridge, respectively. On the Calcutta side of the bridge, six pylons were raised with 75MT and 50MT cranes while on the other side, i.e.; Howrah end 50MT crane was used for the installation of the pylons. The cables for the bridge were drawn from the heads of four pylons assisted by the hoist frames of $32 \mathrm{MT}$ and were arranged on the top of each pylon. The cables inside the pylons were overstretched using jacks and sheave block, winches and snatch blocks were used to ease the process of lifting. Pressure grouting was done in order to fill the voids between the wires and the HDPE (high-density polyethylene) tubes.[46]

The main span of the bridge was constructed from both sides as cantilever with the help desk erection crane. The cantilever grid was held by the erecting cables from the pylon head. As the design of the bridge was followed as per philosophy of dead load composite, the concreting work of the deck slab was done by the four panels of the steel work. The cantilever arrangement of the deck grid supported the cables and short-term bracings were built for the lateral stability of the deck. Some other necessary elements those are needed in the bridge structure are the handrails, different types of lightning rods or spike arrester, traffic barriers, gas service support structures, electronic and telephone lines, elevators, and a maintenance gantry.[47]

\section{Specific features of all the bridges}

Following are the combined data that are summarized in the following table.
Table 19. Combine data.

\begin{tabular}{|l|c|c|c|c|c|c|}
\hline Parameters & BWSL & $\begin{array}{l}\text { Naini } \\
\text { Bridge }\end{array}$ & $\begin{array}{l}\text { Surat } \\
\text { Bridge }\end{array}$ & $\begin{array}{l}\text { Signature } \\
\text { Bridge }\end{array}$ & $\begin{array}{l}\text { Kota } \\
\text { Chambal } \\
\text { Bridge }\end{array}$ & $\begin{array}{l}\text { Vidhyasagar } \\
\text { Setu Bridge }\end{array}$ \\
\hline $\begin{array}{l}\text { Pylon } \\
\text { Height (m) }\end{array}$ & 126 & 90 & 35 & 165 & 80 & 127.62 \\
\hline $\begin{array}{l}\text { No. of } \\
\text { Lanes }\end{array}$ & 8 & 4 & 4 & 8 & 6 & 3 \\
\hline $\begin{array}{l}\text { Longest } \\
\text { span (m) }\end{array}$ & 500 & 260 & 150 & 675 & 350 & 457.27 \\
\hline $\begin{array}{l}\text { Total } \\
\text { Length (m) }\end{array}$ & 4700 & 1510 & 918.21 & 675 & 1500 & 822.96 \\
\hline $\begin{array}{l}\text { Main Span } \\
\text { (m) }\end{array}$ & 4700 & 260 & 712.037 & 251 & 350 & 457.20 \\
\hline $\begin{array}{l}\text { Types of } \\
\text { Foundation }\end{array}$ & Pile.F & Well.F & Pile.F & Well.F & Rect.F & Well.F \\
\hline
\end{tabular}

\section{Longest Span, Main Span, Total}

length Distribution

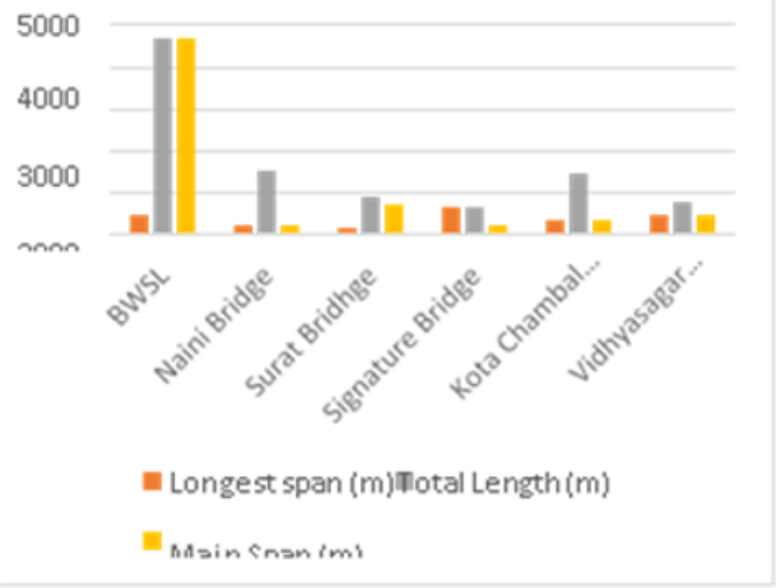

Fig. 9. Determining long span, total length and main span.

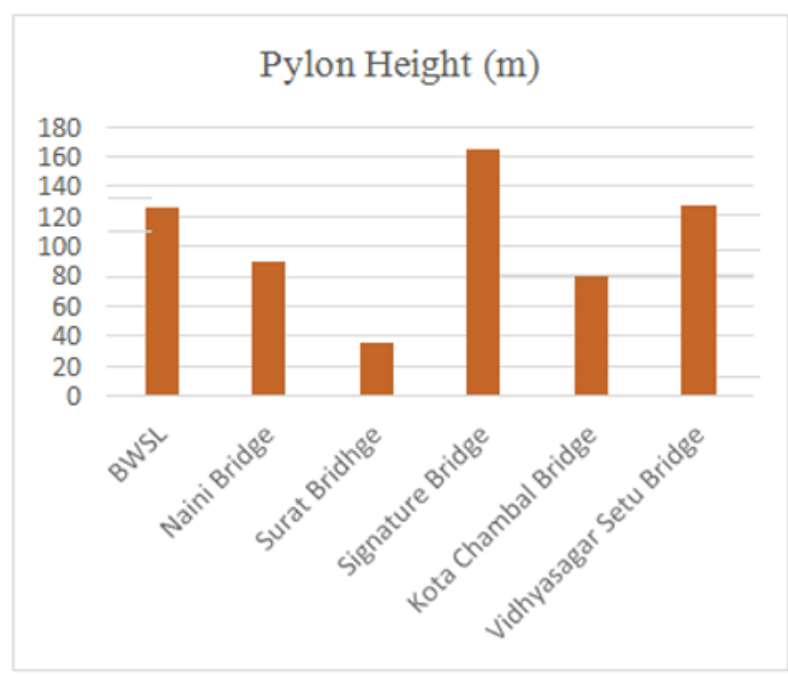

Fig. 10. Determining Pylon height in meters. 


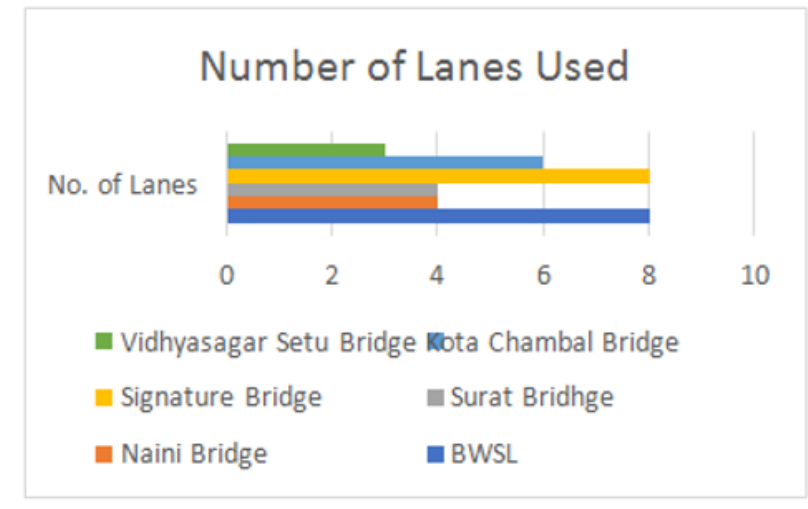

Fig. 11. Determining Number of lanes.

\section{Results and Discussion}

In this research, by studying and understanding the structural design of different cable stayed bridges across India. The inspection of structural details and design considerations of mentioned bridges in this research has developed an outcome which states that the functioning of cable stayed bridges has advanced with time, although every bridge has its own unique design and a purpose to serve, the Signature Bridge in new Delhi is one of its kind, made with cutting edge technology and advance engineering tools which makes this bridge unique in its design, effective and escalates the service life of the structure. While the design of Y-typed Inclined Pylons has left a symbolic impression, the slender composite deck has been an adequate solution for constructing an effective structure. The Graphical Imprints on the structural member has been done for the first time in the history of bridges which illustrate the combination aspect of cultural and modern India.

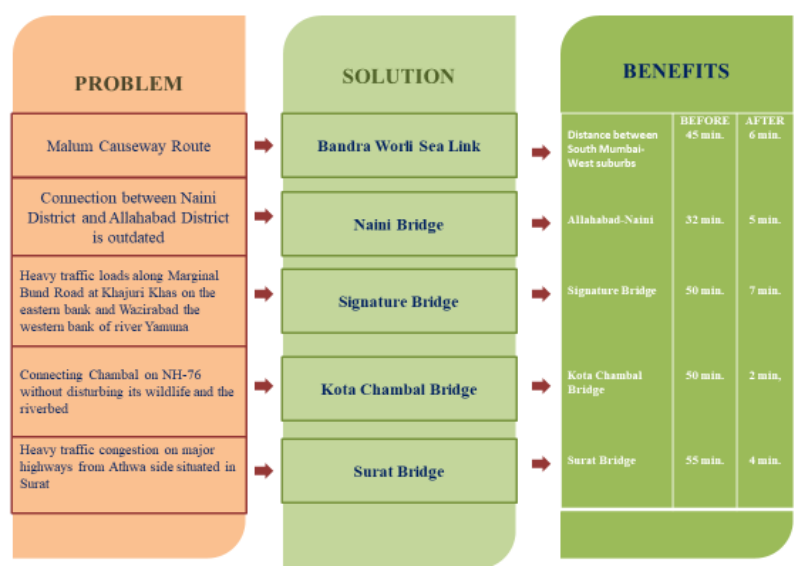

Fig. 12. Results and Discussion.

\section{Conclusion}

In the world where Cities are known by their bridges, these cables stayed bridges has always been spotted at the top. The structural elements of cable stayed bridge make them the strongest, effective and fastest developing bridge system in the world. The cable Stayed bridge gives designer an opportunity to choose from multiple design models which allows engineers and architects to create more innovative, visionary and productive structural design which are largely efficient for longspan bridges. This type of bridge has always been an effective solution for project budget management, material use and construction time-saving.

In this study, we have observed that cable stayed bridges has developed by time with respect to advance engineering technologies and high-strength materials, which makes them more valuable for engineers and construction companies. The cable stayed bridges are more preferable and has been the ideal solution for bridge system by various engineers and designers around the world when working on a new project.

Based on Recent development in construction technologies, the cable stayed has uplifted the infrastructure with these fastest developing, elegant and efficient structures and with everyday progress in the development of the cable stayed bridge may increase the range of the main span length which would effective for long span bridges.

Constructing cable stayed bridges boosts the bridge engineering industry to work on new innovative ideas to build such structures and attains the top preference of designers and construction companies for constructing a long span bridge.

Determination of the case studies and the purpose of implying the importance and interest of cable stayed bridges in India along with the common parameters have proven that the cable stayed bridges have been one of the most efficient design of bridges in this modern era.

\section{References}

1. Arora, I., Singh, R., A., \& Pandit, P., "A Review on the study of cable stayed bridges".,4,1-4(7,2017). https://www.irjet.net/archives/V4/i7/IRJETV4I7249.pdf

2. Krishna, P.," Review article-Tension roofs and bridges ", (Journal of Constructional Steel Research, Vol. 57, 1123-1140, 2001).

3. Zaffar, Iqra, and Priyanka Singh. "Analysis and Design of Deck Slab Bridge." Journal of Civil Engineering and Environmental Technology 3, no. 6 (2016): 517-522.

4. Savaliya, Ghanshyam and Desai, A.K. and V. Sandeep, "The Effect of Side Span Length on the Behavior of Long-Span Hybrid Cable-Stayed Suspension Bridge "(June 8, 2015). (The IUP Journal of Structural Engineering, Vol. VII, No. 3, 47-55 July 2014,)

5. Public Works Research Institute (PWRI). "Seismic design procedure of cable stayed bridges. Part I: dynamic characteristics of cable-stayed bridges based on field vibration test results. Technical report, Tsukuba, Japan;" (1986)

6. Ali, A-Ghaffar AM. "Modeling the nonlinear seismic behavior of cable stayed bridges with passive control bearings. Comput Struct";54(3):461-92. (1995) 
7. C. Tembhekar. "Sea link finances cause concern Mumbai - City - The Times of India". (The Times of India). Retrieved 3 August (2010)

8. IJSRD - International Journal for Scientific Research \& Development| Vol. 4, Issue 03, (2016) ISSN (online): 2321-0613

9. HCC, Bandra Worli Sea Link Project - Construction Methods, HCC India Website, [Online] 2008.

10. Dar Consultants. Bandra Worli Sea Link. [Online] 2008.

11. M. Bose, Bandra-Worli Seal Link an Engineering Marvel, Science Reporter,1-5 (2010)

12. https://www.roadtraffictechnology.com/projects/ban dra/

13. Bandra-Worli Sea Link - Mumbai, India. Waymarking. [Online] April 2009.

14. Walther, Rene, et al. Cable Stayed Bridges. s.l. : T Telford, ( London, 1988)

15. Conrad, W. Felice and B, Henry. Drilled Shaft Construction for the Bandra Worli Sea Link Project., pp. 84-95. (2004)

16. Eastern freeway to have seismic arresters - Mumbai - DNA Archived 13 March 2013 at the Wayback Machine.Dnaindia.com.

17. Y. Bandra Worli Sea link, [Slides]. Slideshare. https://www.slideshare.net/yousufcaptain/bandraworli-sealink (2009)

18. Presentation On Bandra Worli Sealink[Slides].Slideshare. https://www.slideshare.net/priyank123/presentationon-bandra-worli-sealink (2009)

19. Mumbai: Bandra-Worli sea link toll increased; commuters unhappy. The Indian Express. https://indianexpress.com/article/cities/mumbai/mu mbai- bandra-worli-sea-link-toll-increasedcommuters- $\quad$ unhappy5118957/\#:\%7E:text=According\%20to\%20the\%20

Maha

rashtra\%20State, $105 \% 20$ for\%20a\%20return\%20trip

20. Mid-Day Mumbai. "Mumbai: Bandra-Worli Sea Link toll to increase from tomorrow". Archived from the original on 31 March 2015.

21. A 49-year plan for a 15-minute ride - india. Hindustan Times. https://www.hindustantimes.com/india/a-49-yearplan-for-a-15-minute-ride/story4Tdkkdd0UrTJHKoWRZ04XM.html

22. https://msrdc.org/Site/Home/Index.aspx (2009, June 29).

23. Dayaratnam, P.; "Indian Institution of Bridge Engineers (2000). International Conference on Suspension, Cable Supported, and Cable Stayed Bridges": November 19-21, 1999, Hyderabad. Universities Press (India) Limited. p. 204. ISBN 9788173712715. Retrieved 24 June 2015.
Universities Press (India) Limited. p. 204. ISBN 9788173712715. Retrieved 24 June 2015.

24. Rationalisation of Numbering Systems of National Highways" (PDF). New Delhi: Department of Road Transport and Highways. Archived from the original (PDF) on 1 February 2016. Retrieved 3 April 2012.

25. International Conference on Suspension, Cable Supported, and Cable Stayed, page no 204-205

26. http://www.jica.go.jp/english/our_work/evaluation/o da_loan/post/2007/pdf/project30_full.pdf

27. Structurae.. Naini Bridge (2016, February 5) (Allahabad, 2004). https://structurae.net/en/structures/naini-bridge

28. The New Yamuna Bridge | District Prayagraj, Government of Uttar Pradesh | India. https://prayagraj.nic.in/tourist-place/the-newyamuna-bridge/

29. WooCommerce, S. W. B. (n.d.). Yamuna Bridge Naini-Allahabad, India - Our Projects | Encardio Rite. Encardio-Rite Electronics Pvt. Ltd. https://www.encardio.com/yamuna-bridge/

30. https://nhai.gov.in/

31. Railways suspends traffic on Old Yamuna Bridge, https://www.thequint.com/news/hot- news/railwayssuspends-traffic-on-old-yamuna- bridge (2019)

32. ". Indian Kanoon. Archived from the original on 2020-06-16. Retrieved 2020-05-24. 28 August 2014. "Gujarat High Court

33. "5 die as slab of under-construction bridge falls". The Indian Express. 2014-06-11. Archived from the original on 2020-06-16. Retrieved 2020-05-25.

34. "SMC: BRTS Project disclosure 2018" (PDF). Surat Municipal Corporation.

35. Construction of Shree Nathji Fly Over Bridge on Varachha main Road, Surat https://www.suratmunicipal.gov.in/Departments/Bri dgeP rojects?ProjectID=40

36. India Smart City Challenge- Stage 2 https://www.suratmunicipal.gov.in/Content/Docume nts/ Departments/CESpecial/SuratSmartCitySCP.pdf

37. Times of India, Cable-stayed bridge to be inaugurated on Gandhi Jayanti (2018): ):https://timesofindia.indiatimes.com/city/surat/cab le-stayed-bridge-to-be-inaugurated-on-gandhijayanti/articleshow/65971676.cms

38. BridgeProjects.. Construction of " Pandit Dindayal Upadhyay " Cable Stay Bridge across River Tapi Joining Athwa \& Adajan. (2017) https://www.suratmunicipal.gov.in/Departments/Bri dgeP rojects?ProjectID=65

39. SURAT MUNICIPAL CORPORATION (S.M.C.). ENVIRONMENTAL IMPACT ASSESSMENT AND EMP REPORT. en-VISIOn ENVIRO TECHNOLOGIES PVT. LTD. (2017, April). http://environmentclearance.nic.in/DownloadPfdFile .asx?FileName $=$ NPqK0sS8FiU0WZDFdRsnGF+XT $\mathrm{Xcnhh}$ 
RxtF+dd+akWQnjZAEu44WoUw0HW2AbKQBmo

$\mathrm{e} / \mathrm{Pg}$

uFbvMu8Q64d24BiuQ==\&FilePath=93ZZBm8LW

EXf

g+HAlQix2fE2t8z/pgnoBhDlYdZCxzUeqEISsDpN mao zay3MPM7v

40. Construction of "Pandit Dindayal Upadhyay" Cable Stay Bridge across river Tapi joining Athwa \& Adajan.

http://suratmunicipalcorporation.org:8020/Bridge Cell/RiverBridge/RIVERB_13.pdf

41. https://www.sbp.de/en/project/yamuna-bridge-atwazirabad/

42. http://www.gammonindia.com/mediacentre/pdfs/sig n ature-bridge-article.pdf

43. https://en.wikipedia.org/wiki/Signature_Bridge

44. https://timesofindia.indiatimes.com/city/jaipur/kotahanging-bridge-a-dream-turns-intoreality/articleshow/60282670.cms

45. https://www.nbmcw.com/tech-articles/bridges/477chambal-cable-stayed-bridge-connectingshores.html

46. https://bbjconst.com/featured-vidyasagar-setubridge.html

47. https://www.ijser.org/paper/Howrah-Bridge-andSecond-Hooghly-Bridge-A-ComprehensiveComparative-Study.html

48. Schlaich, M., Banerjee, S., \& Sen, S.. Condition of Vidyasagar Setu - Cable-Stayed Bridge in Kolkata. IABSE Symposium Report, 101(21), 1-5. doi:10.2749/222137813808626713 (2013) 